\title{
PROCEEDINGS OF CBU
}

\section{CBU International Conference Proceedings 2015:}

\section{Innovations in Science and Education}

Editors:

Petr Hájek

Pete Mumanachit

Mary-Anne Jones

25-27 March 2015

Prague, Czech Republic

Organized by

Central Bohemia University, o.p.s., Prague, Czech Republic

Unicorn College s.r.o., Prague

Publisher

Central Bohemia University, o.p.s., Prague, Czech Republic

Proceedings of CBU 1805-9961, Vol. 3

Central Bohemia University is a nonprofit private university.

www.cbuni.cz

International Conference on Innovations in Science and Education 2015: edited by Petr Hájek, Pete Mumanachit, Mary-Anne Jones, Proc. of CBU Vol. 3, E-ISSN 1805-9961 (Online).

http://dx.doi.org/10.12955/cbup.v3.677 
As this is a serial book published annually, it has both ISSN and ISBN. ISSN links to whole series of proceedings based on CBU International Conferences while ISBN links to this specific issue in 2015. Each article has also its own unique permanent DOI number which is located on the first page. A digital object identifier (DOI) is a unique alphanumeric string to identify content and provide a persistent link to its location on the internet. All DOI numbers begin with a 10 and contain a prefix and a sufix separeted by a slash. The prefix is number of four or more digits assigned to organizations; the sufix is assigned by the publisher. All articles were peer reviewed.

Please use the following format to cite material from this book:

Author, A., A. \& Author, B., B. (2015). TITTLE OF PAPER. CBU International Conference

Proceedings, 3. doi: Article DOI.

ISBN 978-80-88042-02-0 (Online)

ISSN 1805-9961 (Online)

Published by

Central Bohemia University, o.p.s.

Pod Vodárenskou věží 4,

18200 Praha 8,

Czech Republic

September 19, 2015

Printed in the Czech Republic with ISSN 1805-997X and ISBN 978-80-88042-00-6 (Print).

CBU International Conference Website

www.cbuic.cz, info@cbuni.cz

ojs.journals.cz

Publication of record for individual papers is online in the CBU Digital Library: ojs.journals.cz. This website is used to distribute the articles into various databases. For citing online articles please use

E-ISSN (Online ISSN).

Copyright information:

Authors retain copyright and grant the journal right of first publication with the work simultaneously licensed under a Creative Commons Attribution License 3.0 (CC BY 3.0) that allows others to share the work with an acknowledgement of the work's authorship and initial publication in this journal.

Authors are able to enter into separate, additional contractual arrangements for the non-exclusive distribution of the journal's published version of the work (e.g., post it to an institutional repository or publish it in a book), with an acknowledgement of its initial publication in this journal.

Authors are permitted and encouraged to post their work online (e.g., in institutional repositories or on their website) prior to and during the submission process, as it can lead to productive exchanges, as well as earlier and greater citation of published work (See The Effect of Open Access).

\section{The conference Keynote speakers:}

David Hartman, Unicorn College, Academy of Sciences of the Czech Republic, Charles University in Prague,

Michal Kokorčený, Unicorn College, Prague

Jan Soumar, Charles University in Prague

Petr Hájek, Central Bohemia University, Prague 
Table of contents

VIII Conference chairs

VIII Editorial committees

XI Introduction

Economics and Business

CREATIVITY AS A SUCCESS FACTOR IN PROMOTIONAL ASPECT OF PRODUCTS IN PRODUCTION COMPANIES.

Rajan Arapi

http://dx.doi.org/10.12955/cbup.v3.576

THE VARIANCE AND TREND OF INTEREST RATE - CASE OF COMMERCIAL BANKS IN

KOSOVO.

Fidane Spahija

http://dx.doi.org/10.12955/cbup.v3.577

FOREIGN LANGUAGE COMPETENCE AS A PART OF THE COMMUNICATION CAPITAL OF MANAGERIAL STAFF. 14-19

Elena Delgadová, Monika Gullerová

http://dx.doi.org/10.12955/cbup.v3.578

DASHBOARD USABILITY IN FINANCIAL MODELING.

Ivan Stríček, Ivana Andrisková

http://dx.doi.org/10.12955/cbup.v3.579

CONTEMPORARY CONSUMER IN THE GLOBAL ENVIRONMENT

Aleksandar Grubor, Dražen Marić

http://dx.doi.org/10.12955/cbup.v3.580

THE CHALLENGE OF SUPPORTING CREATIVE INDUSTRIES - SCOTTISH

EXAMPLE.

Joanna Markiewicz

http://dx.doi.org/10.12955/cbup.v3.581

OPTIMIZATION OF POSTAL ROUTES BY GENETIC ALGORITHM FOR SOLVING THE MULTIPLE TRAVELING SALESMAN PROBLEM.

Martin Macik, Jozef Štefunko

http://dx.doi.org/10.12955/cbup.v3.582

CHARACTERISTICS AND DEVELOPMENT OF PROGRAM BUDGETING IN

SELF-GOVERNING REGION.

Viktor Šoltés, Katarína Štofková

http://dx.doi.org/10.12955/cbup.v3.583

SELECTING A COMPETITIVE STRATEGY FOR MANUFACTURING COMPANY USING THE ANALYTIC HIERARCHY PROCESS. $56-63$

Irina Bondareva, Irina Druzhinina, Róbert Tomčík

http://dx.doi.org/10.12955/cbup.v3.584 
HOW TO SELECT APPROPRIATE HUMAN RESOURCE CONTROLLING

INDICATORS

Monika Dugelova, Mariana Strenitzerova

http://dx.doi.org/10.12955/cbup.v3.585

ALLOCATION OF POSTAL NETWORK FACILITIES, BASED ON EXISTING ROAD

INFRASTRUCTURE. $75-81$

Jozef Štefunko, Radovan Madleñák

http://dx.doi.org/10.12955/cbup.v3.586

IMPORTANCE OF REPUTATION IN THE ASSESSMENT OF CORPORATE SOCIAL RESPONSIBILITY $82-88$

Lukáš Vartiak

http://dx.doi.org/10.12955/cbup.v3.587

THE IMPORTANCE AND DESIGN OF WEB-HOSTING SERVICE AT THE UNIVERSITY OF ZILINA 89-94

Martin Hudák, Radovan Madleňák

http://dx.doi.org/10.12955/cbup.v3.588

APPLICATION OF CREATIVITY IN THE EDUCATIONAL PROCESS

Ivana Dudová, Jakub Cíba

http://dx.doi.org/10.12955/cbup.v3.589

DIFFUSION OF KNOWLEDGE IN ORGANIZATION FROM CULTURAL AND NETWORK

PERSPECTIVE. $102-108$

Agnieszka Marek, Kalina Grzesiuk

http://dx.doi.org/10.12955/cbup.v3.590

ESTIMATING THE PARAMETER DELTA IN THE BLACK MODEL USING THE FINITE DIFFERENCE METHOD FOR FUTURES OPTIONS. 109-114

Lucia Švábová

http://dx.doi.org/10.12955/cbup.v3.591

IMPROVEMENT OF COMPANY MARKETING STRATEGY BASED ON ANALYSIS OF GOOGLE SEARCH RESULTS. $115-122$

Marek Ďurica, Lucia Švábová

http://dx.doi.org/10.12955/cbup.v3.592

MODIFICATION OF DELTA FOR CHOOSER OPTIONS

$123-128$

Marek Durica

http://dx.doi.org/10.12955/cbup.v3.593

THE MODERN STATE OF ENTERPRISE INNOVATION ACTIVITY IN

KAZAKHSTAN $129-140$

Nurlan Kurmanov, Dina Aibosynova

http://dx.doi.org/10.12955/cbup.v3.594

HIGHER EDUCATION IN THE REPUBLIC OF KAZAKHSTAN: PROBLEMS AND

IMPROVEMENT METHODS.

Ulukbek Aliyev, Nurlan Kurmanov

http://dx.doi.org/10.12955/cbup.v3.595 
MANAGEMENT MOTIVATION IN THE COMPANIES IN KAZAKHSTAN

Talgat Uteubayev

http://dx.doi.org/10.12955/cbup.v3.596

APPLICATION OF THE GROSS ERROR ANALYSIS TO DISORDERS IDENTIFICATION IN

MANUFACTURING PROCESS--A CASE STUDY

$158-164$

Izabela Dagmara Czabak-Górska, Aneta Kucińska-Landwójtowicz

http://dx.doi.org/10.12955/cbup.v3.597

THEORETICAL AND METHODICAL BASES OF CONSTRUCTING THE ACCOUNTING SYSTEM AND COST ANALYSIS FOR THE PRODUCTION COST OF THE

FOOD INDUSTRY OF KAZAKHSTAN.

Saule Spatayeva, Diana Ismailova, Almagul Nurgalieva

http://dx.doi.org/10.12955/cbup.v3.598

INFLUENCE OF FINANCIAL SECTOR DEVELOPMENT ON ECONOMIC

GROWTH $181-187$

Dilbar Abidova

http://dx.doi.org/10.12955/cbup.v3.600

ESTIMATING VALUE-AT-RISK BASED ON NON-NORMAL DISTRIBUTIONS.

188-195

Mária Bohdalová, Michal Greguš

http://dx.doi.org/10.12955/cbup.v3.601

THE ISSUES OF SUSTAINABLE ECONOMIC GROWTH. .

$196-212$

Ulugbek Azizov

http://dx.doi.org/10.12955/cbup.v3.602

PERSONAL FINANCE MANAGEMENT IN POLAND FROM 2004-2013.

Marta Musiat

http://dx.doi.org/10.12955/cbup.v3.603

A PROPOSAL OF A PROCESS MODEL FOR POSTAL ELECTRONIC SERVICE

IMPLEMENTATION

Bystrik Nemček, Iveta Kremeňová

http://dx.doi.org/10.12955/cbup.v3.604

USE OF FINANCIAL AND NON - FINANCIAL INDICATORS IN EVALUATION OF THE COMPANY'S PERFORMANCE.

Inta Kotane

http://dx.doi.org/10.12955/cbup.v3.605

FOREIGN INVESTMENTS AND FISCAL STIMULATION IN UZBEKISTAN

Nargiza Yakubova

http://dx.doi.org/10.12955/cbup.v3.607

SELECTED FACTORS DETERMINING THE PERFORMANCE OF THE CZECH PUBLIC

PROCUREMENT SYSTEM

Marketa Sumpikova, Juraj Nemec, Marta Orviska, Matúš Grega

http://dx.doi.org/10.12955/cbup.v3.608

CORPORATE GOVERNANCE IN ROMANIA

$248-252$

Ciprian Apostol

http://dx.doi.org/10.12955/cbup.v3.649 
BALANCED SCORECARD AS A STRATEGIC TOOL FOR MANAGEMENT OF PUBLIC ADMINISTRATION

Peter Skotnický

http://dx.doi.org/10.12955/cbup.v3.650

\section{Social Sciences}

QUALITY OF LIFE COMPARISON OF PEOPLE WITH AND WITHOUT DIABETES MELLITUS. $258-262$

Eva Živčicová, Monika Gullerová

http://dx.doi.org/10.12955/cbup.v3.609

INNOVATIONS FOR STRUCTURAL SYSTEM EDUCATION IN ARCHITECTURE....

Saniye Karaman Öztaş, Cahide Aydin İpekçi

http://dx.doi.org/10.12955/cbup.v3.610

IMPORTANCE OF PATENT AND INNOVATION IN EDUCATIONAL INSTITUTIONS

Mario Al Kassiri, Tatiana Čorejová

http://dx.doi.org/10.12955/cbup.v3.611

DIFFERENTIATED ASSESSMENT OF ANXIETY IN ELDERLY WOMEN.

Anatolii Vladimirovich Gribanov, Irina Sergeevna Deputat, Yulia Sergeevna Dzhos, Alexandra Nikolaevna Nehoroshkova, Irina Leopolidovna Bolshevidtseva, Yana Vladimirovna Kereush, Irina Nikolaevna Deryabina, Larisa Fedorovna Startseva, Tatyana Valerjevna Emeljyanova, Tatyana Vladimirovna Bagretsova, Irina Victorovna Ikonnikova http://dx.doi.org/10.12955/cbup.v3.612

BEST AVAILABLE TECHNIQUES AS ENVIRONMENTAL SAFETY ENHANCEMENT INSTRUMENTS. $282-288$

Michael Begak, Tatiana Guseva, Yana Molchanova, Alexander Malkov

http://dx.doi.org/10.12955/cbup.v3.613

CULTURAL LANDSCAPES AND LOCAL IDENTITIES IN THE DEVELOPMENT

OF EASTERN SIBERIAN CITIES (FROM LATE 18TH TO EARLY 19TH CENTURY) $.289-296$

Maria Mihailovna Plotnikova

http://dx.doi.org/10.12955/cbup.v3.614

ADVERTISING WITH SOCIAL DISCOURSE AS A BRAND POSITIONING TECHNIQUE: REVIEW OF RESEARCH WITH SPECIAL REFERENCE TO THE LATVIAN MEDIA.. Aivars Helde

http://dx.doi.org/10.12955/cbup.v3.615

THE PROTECTION OF INVESTORS' RIGHTS IN KAZAKHSTAN

Madina Shegirbayeva, Ozhet Shegirbayev

http://dx.doi.org/10.12955/cbup.v3.616

HIGHER EDUCATION INTERVENTIONS IN THE EU FUNDING CONTEXT DURING 2007 - 2013 PROGRAMING PERIOD IN BULGARIA.

Peter Ivanov

http://dx.doi.org/10.12955/cbup.v3.617

THE YOUNG GENERATION'S ATTITUDE TOWARD RETIREMENT.

http://dx.doi.org/10.12955/cbup.v3.618 
NATIONAL ISSUES IN V. G. KOROLENKO'S ESSAYS

Viacheslav Nikolaevich Krylov

http://dx.doi.org/10.12955/cbup.v3.619

MOVING BEYOND LANGUAGE: AWARENESS OF EFL LEARNERS IN TARGET LANGUAGE CULTURE

Devrim Hol, Ali Erarslan

http://dx.doi.org/10.12955/cbup.v3.620

PEDAGOGICAL EDUCATION IN RUSSIA: CHALLENGES, PROSPECTS, AND QUALITY ASSURANCE

Irina Kulikovskaya, Anna Andrienko

http://dx.doi.org/10.12955/cbup.v3.621

LITERARY TEXT AS A SOURCE FOR UNDERSTANDING CONFLICTS IN CONTEMPORARY REALITY (POLITICAL VIOLENCE AND TERRORISM)

Tatiana Voronchenko, Olesya Kovrizhnykh, Ekaterina Fyodorova

http://dx.doi.org/10.12955/cbup.v3.622

SOME ASPECTS OF AGILE APPROACH IN PRAXIS

Jaroslava Kniežová

http://dx.doi.org/10.12955/cbup.v3.623

SOCIAL ASPECTS OF ARCHITECTURAL DEVELOPMENT IN NORTHERN

KAZAKHSTAN

Olga Semenyuk, Rakhima Chekaeva, Farid Chekaev

http://dx.doi.org/10.12955/cbup.v3.624

THE CONSUMER AS A SOURCE OF MARKETING INFORMATION IN THE INFORMATION SOCIETY...

Kamila Peszko

http://dx.doi.org/10.12955/cbup.v3.625

WAYS OF OVERCOMING SOCIAL INEQUALITY BY THE KAZAKH NOMADS

IN THE BOOK OF ABAI KUNANBAEV "THE WORDS OF EDIFICATION". $368-370$

Kulush Kenzhegaliev

http://dx.doi.org/10.12955/cbup.v3.626

ENERGY PARAMETERS OF KAZAKHSTAN-AMERICAN RELATIONS:

GEOPOLITICAL AND INTERNATIONALLY LEGAL ASPECTS.

Bekbolat Bakbergenovich Almadiyev

http://dx.doi.org/10.12955/cbup.v3.627

ENSURING INTERETHNIC CONCORD: CASE OF KAZAKHSTAN....

$378-382$

Maral Zhanarstanova, Elena Nechaeva

http://dx.doi.org/10.12955/cbup.v3.654

INTERACTION OF PARLIAMENTS WITH EXECUTIVE BRANCHES IN POST-SOCIALIST

ROMANIA AND KAZAKHSTAN: COMPARATIVE ANALYSIS

Timur Kanapyanov, Naubat Kaliyev

http://dx.doi.org/10.12955/cbup.v3.655 
Medicine and Pharmacy

PRESENTATION OF RECEPTOR-CONTACTING LOOP OF HUMAN IGE ON THE HBCAG

PARTICLES

Aliya Zhanatayevna Baltabekova, Alexander Vyacheslavovich Shustov

http://dx.doi.org/10.12955/cbup.v3.628

DEVELOPMENT OF AUTONOMOUSLY REPLICATING VIRAL RNA TO EXPRESS THE RECOMBINANT HUMAN GRANULOCYTE COLONY-STIMULATING FACTOR.... 398-404 Makhabbat Kaliyeva, Alexander Shustov

http://dx.doi.org/10.12955/cbup.v3.629

PREPARATION OF CHEMICAL AND PHYSICAL CONJUGATES OF SELF-ASSEMBLING

NANOPARTICLES WITH CELL-PENETRATING PEPTIDE AND DOXORUBICIN.... 405-411

Zhadyra Sagykyzy Shagyrova, Yerzhan Yersaiynuly Zhiyenbay, Mikhail Sergeyevich Voikov,

Alexander Vyacheslavovich Shustov

http://dx.doi.org/10.12955/cbup.v3.630

RECOMBINANT THERMOTOLERANT PHYTASE PRODUCED IN E.COLI.

$412-418$

Altynai Seitkhanovna Axambayeva, Alexander Vyacheslavovich Shustov

http://dx.doi.org/10.12955/cbup.v3.631

PATIENT SATISFACTION WITH ORTHOPEDIC AND PROSTHETIC MEDICAL

DEVICES.

Ivona Malovecká, Daniela Mináriková, Viliam Foltán

http://dx.doi.org/10.12955/cbup.v3.632

THE PATHOLOGICAL MORPHOLOGY OF PIROPLASMOSIS IN CATTLE.

$427-431$

Aizhan Balgimbaeva, Gulnar Schabdarbaeva, Assem Ibazhanova, Zhuldyzay Kenzhebekova

http://dx.doi.org/10.12955/cbup.v3.633

THE EFFECT OF CONTINUOUS SUBCUTANEOUS INSULIN INFUSION TREATMENT,

INSULIN ANALOG AND HUMAN INSULIN OF CHILDREN WITH DIABETES. $432-436$

Elina Petkova, Valentina Petkova, Guenka Petrova, Maya Konstantinova

http://dx.doi.org/10.12955/cbup.v3.634

USE OF METHYL JASMONATE TO ENHANCE THE PRODUCTION OF 6-METHOXYPODOPHYLLOTOXIN IN CELL CULTURES OF LINUM THRACICUM SSP. THRACICUM. $437-443$

Pavlina Sasheva, Iliana Ionkova

http://dx.doi.org/10.12955/cbup.v3.635

LOCAL COMPLEX TREATMENT EXPERIENCE FOR PATIENTS WITH CHRONIC

PURULENT OTITIS MEDIA. $444-446$

Nilufar Jurakulovna Khushvakova, Nargiza Orzuevna Khamrakulova

http://dx.doi.org/10.12955/cbup.v3.636

Natural Sciences and ICT

COMPOSITION OF MAJOR ORGANIC ACIDS IN VEGETABLES AND SPICES.......

$447-454$

Liga Priecina, Daina Karklina

http://dx.doi.org/10.12955/cbup.v3.637 
OPTIMIZATION OF WHEAT BRAN MEDIUM PROCESSING CONDITIONS, ASSESSMENT OF BIOLOGICAL VALUE FOR SACCHAROMYCES

Victor Panfilov, Boris Karetkin, Mariya Gordienko, Irina Shakir

http://dx.doi.org/10.12955/cbup.v3.638

IMPROVING ENERGY EFFICIENCY OF SILICON CARBIDE CERAMICS PRODUCTION BY

BATCH REGULATION. 461-467

Dmitry Zhukov, Nikolay Makarov, Maria Vartanyan, Tatiana Guseva

http://dx.doi.org/10.12955/cbup.v3.639

APPLICATION OF INFORMATION TECHNOLOGIES AND INTERACTIVE TOOLS

FOR IMPROVING EDUCATIONAL QUALITY. $468-474$

Krasimira Georgieva, Vanya Stoykova, Nevena Ivanova, Emiliya Dimova

http://dx.doi.org/10.12955/cbup.v3.640

LABELING OPTIONS FOR POSTAL SHIPMENTS BY PASSIVE RFID

TECHNOLOGY

$475-481$

Ondrej Maslák, Ivana Andrisková

http://dx.doi.org/10.12955/cbup.v3.641

THE USE OF EYE TRACKING TO ASSESS THE USABILITY OF UNIVERSITY

WEBSITE

Terézia Kvasnicová, Iveta Kremeňová

http://dx.doi.org/10.12955/cbup.v3.642

CASE STUDY OF ADMINISTRATIVE PROCESS AUTOMATION IN HIGHER

EDUCATION INSTITUTIONS FROM ROMANIA

Valerică Greavu-Serban

http://dx.doi.org/10.12955/cbup.v3.648

RESEARCH OF PLUM DRYING PROCESS

$494-498$

Nurlan Kurmanov, Azret Shingissov, Gulzhan Kantureyeva, Zeinep Nurseitova,

Baurzhan Tolysbaev, Gulzhanat Shingisova

http://dx.doi.org/10.12955/cbup.v3.643

THE LIMITING STORAGE LIFE OF PERISHABLES DURING JOINT

TRANSPORTATION

Nurlan Kurmanov, Baurzhan Tolysbayev, Yermek Abilmazhinov

http://dx.doi.org/10.12955/cbup.v3.644

SEARCH ENGINE OPTIMIZATION.

$506-510$

Jakub Zilincan

http://dx.doi.org/10.12955/cbup.v3.645

GROWTH AND PRODUCTIVITY OF POPLAR SPECIES IN SOUTHEASTERN

KAZAKHSTAN

Dani Sarsekova

http://dx.doi.org/10.12955/cbup.v3.646

UTILIZATION OF INDUCTION HEATING TECHNOLOGY IN GALVANIZING

LINES.

Victor Demidovich

http://dx.doi.org/10.12955/cbup.v3.647 


\section{Conference chairs}

Petr Hajek, Central Bohemia University, Prague, Czech Republic

David Hartman, Unicorn College, Academy of Sciences of the Czech Republic, Charles University in Prague, Czech Republic

\section{Editorial committees}

\section{Editor-in-chief}

Dr. Petr Hajek, Vice-rector, Central Bohemia University, Prague, Czech Republic

\section{Editors}

Pete Mumanachit, Central Bohemia University

Mary-Anne Jones, Central Bohemia University

\section{Economics and business section committee}

Petr Hajek, Vice-rector, Central Bohemia University, Prague, Czech Republic

Eva Vašková, Victor Pavlik Lawyers LLC. \& Prague Faculty of Law, Charles University in Prague,

Czech Republic

Lukáš Horák, CEO’s Strategic Analyses Department, Ceska Pojistovna Insurance Group Prague,

Czech Republic

Vaidotas Matutis, State Tax Inspectorate, Ministry of Finance, Vilnius (previously also Mount Royal University - Calgary, Alberta, Canada \& Economic Faculty, Mykolas Romeris University, Vilnius),

Lithuania

Michal Brožka, Fixed-Income analyst Macroeconomics - Research Department Raiffeisenbank,

Prague, Czech Republic

Patrik Just, Accounting and Law Specialist, Manifold Group, Plzeň, Czech Republic

Tomáš Voplakal, Charles University in Prague \& Faculty of Finance and Accounting, University of

Economics in Prague \& Ernst and Young, Transaction Advisory services department, Czech Republic

Valentina Shapoval, Department of Corporate Economics, National Mining University

Dnepropetrovsk, Ukraine

Jan Vorlíček, Unicorn College \& College of information Management and Business Administration, Prague, Czech Republic

Eva Kaňková, University of Economics in Prague, Czech University of Life Sciences, Czech Republic Zuzana Svobodová, Department of Management and Marketing ( ̌SAVŠ), Škoda Auto University, Mladá Boleslav, Czech Republic

Jerome Dumetz, Cross Cultural Management Specialist working inParis, Prague, Moscow and SanktPeterburg, organization Clamart, Paris, France

Khaled Zidan Ph.D., Finance department, Faculty of Economics and Social Studies, An-Najah

National University, Nablus, Palestine

Prof. Jan Čadil, Rector of Unicorn College, Prague, Czech Republic

Prof. Kumaraj Sundar, Commerce Wing, Directorate of Distance Education, Annamalai University, India

Drahomír Jančík, Institute of Economic and Social History, Faculty of Arts, Charles University, Prague \& Faculty of Business Administration, University of economics in Prague, Czech Republic Jiří Kleibl, rector of Unicorn College, Prague, Faculty of Business Administration, University of Economics, Prague, Czech Republic

Prof. Miloš Kaňka, Faculty of Informatics and Statistics University of Economics in Prague \& The College of Polytechnics Jihlava, Czech Republic

Akram Jalal Karim, chairman of the Management Information System Department of College of Business and Finance at Ahlia University, Manama, Bahrain

Kholnazar Amonov, member of the board, Central Bohemia University, Prague, Czech Republic 
Prof. Murtaz Kvirkvaia, Dean of the Faculty School of Business and Management, Grigol Robakidze University, Georgia

Hana Kristová, Senior Auditor, Deloitte, Prague, Czech Republic

Viktor Korček, Senior Management and Marketing Consultant \& East-African Project Manager,

Prague, Czech Republic

Pacha Malyadri, Principal, Government Degree College, Osmania University, Hyderabad, Andhra

Pradesh, India

Nurlan Kurmanov, KazEU, Kazakhstan

Quang Van Tran, Faculty of Finance and Accounting, University of Economics in Prague, Czech

Republic

Miroslav Tuček, retired professor, Banking expert, University of Economics in Prague, Czech

Republic

Prof. Tomáš Pavelka, Faculty of Business Administration, University of Economics in Prague, Czech

Republic

\section{Medicine and Pharmacy Section Committee}

Jana Staňurová, Fakultät für Biologie und Vorklinische Medizin, Universität Regensburg, Germany Helena Kristova, Lead clinical research associate, Chiltern International, Prague, Czech Republic Stanislav Janák, Production Director, Škrobárny a.s., Pelhřimov, Czech Republic

Ondřej Lešetický, Department of Management (focus on Medical services), University of Economics in Prague, Czech Republic

Prof. Izzet Yavuz, Faculty of Dentistry, University of Dicle in Diyarbakir, Turkey

Kateřina Bubáková, Faculty of Biomedical Engineering Czech Technical University in Prague Motol University Hospital, Prague, Czech Republic

Eva Tůmová, 3rd Department of Medicine - Department of Endocrinology and Metabolism, First Faculty of Medicine, Charles University in Prague and General University Hospital in Prague, Czech Republic Lucie Pieckova, Faculty of Food and Biochemical Technology Institute of Chemical Technology Prague (VSCHT Chemical University), Czech Republic

Liana Gogiashvili, Head of the Experimental Pathology Department, A. Natishvili Morphology Institute, Tbilisi, Georgia

Prof. Ekaterine Chkhartishvili, Human Histology and Embryology Department, 'AIETI Medical

School (David Tvildiani Medical University), Pediatrician, Intensive Care Department, No.1 Pediatric Clinic, Tbilisi, Georgia

Eliška Potluková, 3rd Department of Medicine - Department of Endocrinology and Metabolism, First Faculty of Medicine, Charles University in Prague and General University Hospital in Prague, Czech Republic

Nakul Vinod Karkare, Orthopaedic surgeon and biomaterials engineer. Loma Linda, CA, United States

Olga Reshetnikova, Medical Faculty, Lugansk State Medical University, Ukraine

\section{Social Sciences Section Committee}

Eva Vašková, Victor Pavlik Lawyers LLC. \& Prague Faculty of Law, Charles University in Prague, Czech Republic

Eduard Kubů, Faculty of Arts, Charles University \& University of Economics in Prague \& Unicorn College, Prague, Czech Republic

Pavel Král, Faculty of Management, University of Economics in Prague, Czech Republic Alexander Lesnik, Vice-rector, University of Economics and Management, Czech Republic

Petr Marek, Department of Finance and Business Valuation, Executive board member of Acta Oeconomica Pragensia, University of Economics in Prague, Czech Republic

Arta Musaraj, Academicus-International Scientific Journal, Deputy Defence Minister, Etc-

Entrepreneurship Training Center, ex-rector of University of Pavaresia, Albania 
Mikheil Gogatishvili, Programme leader of Public Administration, Social and Political sciences, Grigol Robakidze University, Tbilisi, Georgia

Salih Seyhan, Communication Faculty, Journalism Department, Ataturk University, Turkey

Nino Kemertelidze, Vice-rector of Grigol Robakidze University (Heading Scientific Research

Management Centre and Center of International Integration), Tbilisi, Georgia

Daniel Tácha, editor-in-chief of Make Money, a journal published by Financial Media Group, Prague,

Czech Republic

\section{Natural Sciences Section Committee}

Viktor Goliáš, Institute of geochemistry, mineralogy and mineral resources, Faculty of Science, Charles University in Prague, Czech Republic

Libor Voplakal, Faculty of Transportation Sciences, Czech Technical University in Prague, Czech

Republic

Michal Kökörčený, Head of Project Management Department (IT projects), Frederiksgroup \& Unicorn

College, Prague, Czech Republic

Y1lmaz Uyaroğlu, Electrical \& Electronics Engineering Department, Engineering Faculty, Sakarya University, Sakarya, Turkey

Ahmet Çifci, Electrical and Energy Department, Burdur Mehmet Akif Ersoy University, Burdur, Turkey

Uğur Erkin Kocamaz, Computer Technologies Department, Uludağ University, Karacabey, Turkey

Bohumil Havrland, Faculty of Tropical AgriSciences, \& editor-in-chief of Agricultura Tropica Et

Subtropica an indexed journal of Czech University of Life Sciences, Prague, Czech Republic

Ladislav Torčík, CEO, NanoTrade Ltd., Olomouc, Czech Republic

Oldřich Mužík, Research Institute of Agricultural Engineering, Prague, Czech Republic

David Hartman, Head of IT department, Unicorn College, Prague, \& Institute of Computer Science,

Academy of Science of the Czech Republic, \& Department of Applied Mathematics, Charles

University, Prague, Czech Republic

Prof. Zdeněk Zelinger, J. Heyrovský Institute of Physical Chemistry, Academy of Sciences of the

Czech Republic, Prague, Czech Republic

Petr Bitala, Department of Fire Protection, Faculty of Safety Engineering, VŠB-Technical University of Ostrava, Czech Republic

Barbora Baudišová, Laboratory for Risk Research and Management, Faculty of Safety Engineering, \& Energy research center, VŠB-Technical University of Ostrava, Czech Republic

Jan Ptáček, Headmaster of the High School of Chemistry in Pardubice, Czech Republic

Jan Kamenický, Institute of Mechatronics and Computer Engineering, Faculty of Mechatronics,

Informatics and Interdisciplinary studies, Liberec Technical University, Czech Republic

Lenka Hrušková, Institute of geochemistry, mineralogy and mineral resources, Faculty of Science, Charles University in Prague, Czech Republic

Václav Nevrlý, Institute of Thermomechanics, Academy of Sciences of the Czech Republic; Faculty of Safety Engineering, VŠB-Technical University of Ostrava, Czech Republic 


\section{Introduction}

We had the great honor of organizing the CBU International Conference 2015 (CBUIC 2015): Innovations in Science and Education Prague, Czech republic. It was truly a great pleasure for us to greet a lot of participants from many different countries attending CBUIC 2015! We firmly believe that the conference will become an important international event in the field of crossindustry discussion about innovations in Education and Science.

CBUIC 2015 was organized by Central Bohemia University and Unicorn College, Prague, Czech Republic. Proceedings were published by Central Bohemia University.

5 cooperating organizations supported the conference. There were 75 papers accepted for presentation at CBUIC 2015, contributed by over 155 authors from more than 10 countries. We had four plenary speeches and several well-known scientists and experts, to give invited talks at different sessions.

The purpose of CBUIC 2015 was to provide a forum for the participants to report and review innovative ideas, with up-to-date progress and developments, and discuss the novel approaches to application in the field of their own research areas and discuss challenges of doing science and education.

We sincerely hope that the exchange of ideas on doing research, science and improving education will help the participants, and international cooperation sharing the common interest will be enhanced.

On behalf the Organization Committee of CBUIC 2015, we would like to heartily thank our cooperating organizations for all they have done for the conference. We would also like to thank the authors for their contribution to the proceedings; the participants and friends of CBUIC 2015, for their interest and efforts in helping us to make the conference possible; and the Editorial boards for their effective work and valuable advice, especially the CBUIC 2015 Secretariat and the CBU staff, for their tireless efforts and outstanding services in preparing the conference and publishing the Proceedings.

Petr Hájek, Central Bohemia University

David Hartman, Unicorn College

Conference chairs 